\title{
DIREITO E POLÍTICAS PÚBLICAS: UMA VISÃO JURÍDICO- INSTITUCIONAL SOBRE O CASO DO SANEAMENTO BÁSICO NO BRASIL ${ }^{1}$
}

\section{LAW AND PUBLIC POLICY: A LEGAL-INSTITUTIONAL VIEW ON THE CASE OF BASIC SANITATION IN BRAZIL}

SERGIO Ruy DAVID POLIMENO VALENTE ${ }^{2}$

RESUMO: Este artigo objetiva aplicar a visão jurídico-institucional de Direito e Políticas Públicas para examinar características da política nacional de saneamento básico, ressaltando aspectos de método na análise de políticas públicas em geral. Parte-se da base teórica de ciência política, na linha do neoinstitucionalismo histórico, incorporando o ferramental jurídico com vistas a alargar a compreensão do objeto. Características distintivas do neoinstitucionalismo histórico, como a ideia de que as instituições conformam comportamentos, distribuem desigualmente o poder, e de que a trajetória institucional condiciona a formação das políticas servem como premissas, juntamente com a identificação de oportunidades de veto. A noção de política pública formada por processos juridicamente regulados permite estender essa identificação para outras esferas processuais - não somente processo legislativo - e a dogmática possibilita a qualificação jurídica dessas oportunidades de veto para melhor compreensão da dinâmica. A análise do ambiente institucional visa identificar atores e interesses relevantes para o entendimento do arranjo e seus efeitos jurídico-políticos, enquanto a análise da trajetória institucional permite reconhecer características que sofrem dependência de trajetória, transcendendo fatores puramente jurídicos. $\mathrm{O}$ quadro de referência é utilizado para uma visão geral do arranjo, de forma a balizar seu exame crítico. Na observação de processos formadores da política de saneamento, evidencia-se como os diversos interesses influíram sobre a construção do marco normativo e de que maneira esses refletem na sua aplicação. Demonstrase como a omissão sobre disputas redistributivas propicia oportunidades de veto

\footnotetext{
${ }^{1}$ Artigo derivado de dissertação de mestrado defendida em 12 de abril de 2018 na Faculdade de Direito da Universidade de São Paulo, intitulada Políticas públicas e a visão jurídico-institucional: o caso do saneamento básico no Brasil. Orientadora: Professora Maria Paula Dallari Bucci.

${ }^{2}$ Bacharel e mestre em Direito do Estado pela Faculdade de Direito da Universidade de São Paulo, atualmente cursando doutorado pela mesma instituição. Advogado em Brasília. Contato: sergio.valente@bernardesadvogados.adv.br.
} 
juridicamente qualificadas a determinados atores no processo governamental, favorecendo a manutenção do status quo.

Palavras-Chave: Saneamento Básico; Direito e Políticas Públicas; Neoinstitucionalismo Histórico; Dependência de trajetória.

ABSTRACT: This paper aims to apply the legal-institutional view of Law and Public Policy to examine characteristics of the national sanitation policy, highlighting method aspects in the analysis of public policies in general. It starts from the theoretical basis of political science, in line with historical neoinstitutionalism, incorporating the legal tools to broaden the understanding of the object. Distinctive features of historical neoinstitutionalism, such as the idea that institutions conditions behavior, unequally distribute power, and that the institutional trajectory shape policymaking serve as premises, along with identifying veto points. The notion of public policy formed by legally regulated processes allows to extend this identification to other procedural spheres - not only legislative process - and the dogmatic allows the legal qualification of these veto points for a better understanding of the dynamics. The analysis of the institutional environment aims to identify actors and interests relevant to the understanding of the arrangement and its legal-political effects, while the analysis of the institutional trajectory allows to recognize path-dependent characteristics, transcending purely legal factors. The reference frame is used for an overview of the arrangement to guide its critical examination. In the observation of processes that form the sanitation policy, it is evident how the various interests influenced the construction of the normative framework and how they reflect on its application. It is demonstrated how the omission about redistributive disputes provides legally qualified veto points to certain actors in the government process, favoring the maintenance of the status quo.

KeYwORDS: Basic Sanitation; Law and Public Policies; Historical Neoinstitutionalism; Path dependency. 


\section{INTRODUÇÃO}

A análise do desenvolvimento do setor de saneamento no Brasil é de grande relevância social e econômica. Há comprovada relação de causalidade entre a falta de saneamento básico e a proliferação de inúmeras doenças e problemas de saúde. ${ }^{3}$ A questão do saneamento básico é ponto fundamental para a efetivação do direito social à saúde, mas também tem repercussão na efetivação de outros direitos fundamentais, como o direito ao meio ambiente equilibrado, direito ao desenvolvimento e o direito à educação ${ }^{4}$. No Brasil, $93 \%$ da população urbana possui acesso à água tratada, mas somente $60,2 \%$ é atendida com coleta de esgoto e apenas $46 \%$ do volume de esgoto passa por algum tipo de tratamento ${ }^{5}$. Deve-se questionar qual o papel das instituições jurídicas nesse cenário e quais os fatores de influência direta e indireta no quadro atual. O quadro pode se dever, ao menos em parte, a aspectos do desenho jurídico-institucional da política nacional de saneamento, os quais possuem tanto um componente jurídico (relacionado com o sentido normativo das disposições e suas consequências estritamente jurídicas), quanto um componente político (relacionado com os interesses envolvidos na construção de textos normativos, decisões judiciais, nos atos governamentais e suas consequências sociais). O mapeamento de características e deficiências da política visa identificar esses componentes e suas conexões.

A efetividade do direito não advém precipuamente da vontade de gestores ou representantes, mas de uma cultura institucional que reforce o tratamento jurídico sistemático das consequências das ações ${ }^{6}$. Porém, o arranjo jurídico-institucional de qualquer política pública é sempre de alguma forma condicionado ou influenciado pelas disputas de poder entre os mais diversos atores, como partidos políticos, grupos de interesse, governantes e gestores públicos, entre outros. O grau e forma de intervenção do Estado, da ação de atores públicos e privados e a distribuição de competências são exemplos de aspectos diretamente decorrentes de escolhas políticas permeadas por embates essenciais. O presente artigo é uma análise aplicada ao setor de saneamento básico com base na abordagem de Direito e Políticas Públicas, cujas linhas teóricas principais e sistematização se encontram em trabalho de Maria Paula Dallari Bucci ${ }^{7}$, o qual se utiliza como base e ponto de partida. Pretende-se então congregar o componente institucional de contribuição da ciência política com as ferramentas proporcionadas pelo direito para melhor compreender desenvolvimento do fenômeno governamental nessa área específica. Tal abordagem se vale de um instrumental que se amolda à perspectiva de governo, tomando as políticas públicas, conceitualmente, como programas de ação

\footnotetext{
${ }^{3}$ Freitas (2003, p. 609-610).

${ }^{4}$ Instituto Trata Brasil (2010).

5 Dados de 2017. Disponível em: <http://www.snis.gov.br/component/content/article?id=175>. Acesso em: 28 fev. 2019.

${ }^{6}$ Bucci (2013, p. 258).

${ }^{7}$ Bucci (2013).
} 
governamental juridicamente definidos e resultantes de processos 8 juridicamente regulados, com ênfase na escala desses programas e visando à possibilidade prospectiva de análise, ou seja, a capacidade analítica a traçar estratégias jurídicoinstitucionais, por meio da identificação de como atuam os diversos atores e, com base nas instituições, desenvolver visões prospectivas no sentido de sua remodelação para uma maior efetividade? .

\section{MÉTODO - A VISÃo JURÍDICO-INSTITUCIONAL}

A análise jurídico-institucional da política pública de saneamento básico proposta tem como matriz condutora as noções desenvolvidas no âmbito da ciência política, juntamente com a dogmática jurídica como ferramenta analítica, considerando os diversos ramos do direito incidentes sobre o tema, como o direito administrativo, ambiental, financeiro, entre outros. O desafio que se apresenta é a sua aplicação para alcançar resultados práticos, em especial a melhor compreensão das características da política nacional de saneamento básico, seus efeitos e como se apresenta a relação entre política e direito, móvel da ação governamental. De um lado, ela pode transcender os limites das análises focadas nas politics, em que se discutem eminentemente as disputas políticas em torno da formulação de um novo modelo. De outro, pode transcender os estudos jurídicos puramente dogmáticos sobre os instrumentos da política e sua integração no ordenamento.

Na ciência política, o neoinstitucionalismo é a linha teórica desenvolvida buscando explicar como o papel desempenhado pelas instituições influi na determinação de resultados sociais e políticos, e costuma ser dividido em três vertentes: o neoinstitucionalismo da escolha racional, o neoinstitucionalismo histórico e o neoinstitucionalismo sociológico. ${ }^{10}$ No caso da análise aplicada ao saneamento básico, as três características distintivas do neoinstitucionalismo histórico ${ }^{11}$, abordadas abaixo, servem como premissas metodológicas para se alcançar resultados concretos. Em primeiro lugar, tem-se a ideia de que as instituições conformam os comportamentos dos atores, especialmente ao balizarem as expectativas em relação ao comportamento dos demais. No caso em tela, a política nacional de saneamento básico é estruturada essencialmente por marcos legais que compõem arranjos institucionais, os quais pressupõem uma série de interesses e hipóteses de ações sociais que ditam comportamentos negativos e positivos e tratam da organização primordial do contexto no qual os diversos atores poderão planejar suas estratégias, com base na expectativa em relação às estratégias dos demais. Usuários do serviço, prestadores, entes federativos, por exemplo, fundamentam suas ações como consumo, investimento e assunção de riscos com

\footnotetext{
${ }^{8}$ Bucci (2013, p. 109-110).

${ }^{9}$ Bucci (2017, p. 35-38).

${ }^{10}$ Hall e Taylor (1996, p. 936).

${ }^{11}$ Hall e Taylor (1996, p. 939).
} 
base em incentivos e desincentivos que estejam previstos no arranjo jurídicoinstitucional da política. Em segundo lugar, tem-se a noção de que as instituições distribuem o poder de forma desigual, privilegiando determinados atores em detrimento de outros. Ou seja, a depender de como as instituições estejam estruturadas, será conferido maior ou menor poder a certos grupos para influir no resultado dos processos decisórios de uma política. Conforme salienta Celina Souza, essa noção, característica das contribuições neoinstitucionalistas, é importante, já que a luta pelo poder e por recursos é ponto central da formulação de políticas públicas, luta esta "mediada por instituições políticas e econômicas" (e, aqui se acrescenta, jurídicas) "que levam as políticas públicas para certa direção e privilegiam alguns grupos em detrimento de outros" ${ }^{12}$. A disputa de poder entre diversos interesses e a forma como a política nacional de saneamento básico se estruturou para definir sua distribuição é aspecto que pode ser aferido da análise dos processos de mudança institucional ao longo do tempo, com o desenvolvimento incremental das instituições da política de saneamento e a longa fase de embates quando de sua reformulação estrutural após a Constituição de 1988. Em terceiro lugar, a trajetória institucional das situações críticas e contingências (path dependency ${ }^{13}$ ) pode orientar a análise com a especial finalidade de identificar fatores alheios à pura e simples configuração dos arranjos, que possam influir no comportamento dos atores e nos resultados da política pública, como processos sociais baseados em uma dinâmica de "retornos crescentes"14. $\mathrm{O}$ exame institucional em sentido estrito, que considerasse apenas o desenho atual da política, sem se preocupar com o desenvolvimento institucional na experiência histórica, poderia levar a resultados imprecisos. Antes mesmo da aprovação do novo marco regulatório do saneamento, estudos prospectivos já apontavam para a necessidade prática de que o novo marco considerasse as situações de fato consolidadas e que, na sua elaboração, se observasse cuidadosamente o impacto sobre as estruturas de prestação de serviços existentes ${ }^{15}$. Mesmo após a aprovação, essa preocupação remanesce, mas no sentido de aferir como essa estrutura consolidada influencia da dinâmica dos novos arranjos.

\footnotetext{
12 Souza (2007, p. 83).

${ }^{13}$ A ideia de path dependency, advinda da ciência política, possui complexidade conceitual que não será abordada no presente artigo por escolha de método. Cabe frisar, porém, que estudos na linha neoinstitucionalista histórica enfatizam a importância de mecanismos de feedback positivo que induzem à dependência de trajetória, e o entendimento desse processo é útil à proposta. Como exemplo, pode-se citar o mecanismo de feedback circular relacionando ao estabelecimento de programas típicos de um estado de bem-estar social (como uma política de seguridade) com seus destinatários elegíveis. Estes, por sua vez, acabam por formar grupos organizados para defender os programas dos quais se beneficiam contra cortes e reformas. Em razão disso, o programa acaba se tornando resistente a mudanças (ZEHAVI, 2012, p. 313).

${ }^{14}$ A dinâmica de retornos crescentes como característica distintiva da dependência de trajetória é explicada em detalhes por Pierson em trabalho que delineia precisamente os contornos do conceito e sua melhor aplicação na análise de políticas (PIERSON, 2000, p. 251-267).

${ }^{15}$ Coutinho et al. (2006, p 26).
} 
A essas premissas do neoinstitucionalismo histórico soma-se, como critério importante de análise, a aferição sobre a existência, número e qualidade das oportunidades de veto (veto points), critério desenvolvido por Ellen Immergut em artigo comparativo sobre a reforma do sistema de saúde de três países europeus ${ }^{16}$. Na literatura neoinstitucionalista histórica, a identificação de oportunidades de veto no curso da elaboração de uma política pública tornou-se frequente e é considerada uma ferramenta analítica poderosa ${ }^{17}$. Constituem oportunidades de veto, por exemplo, a convocação de um referendo, o veto presidencial, o poder de pauta, e as instâncias de aprovação legislativa em duas câmaras, entre outros elementos. A identificação de oportunidades de veto, aliada às ferramentas proporcionadas pela dogmática jurídica, se mostra útil para delinear algumas das disfunções jurídico-institucionais do setor de saneamento.

O referencial interdisciplinar acima mencionado servirá como caminho para a estruturação de uma análise aplicada que conjugue a utilidade da dogmática jurídica e de formulações da ciência política neoinstitucionalista histórica para melhor entender um problema dado, como o funcionamento ou embaraço de uma política pública em face dos resultados que apresenta e aqueles que se propõe atingir.

\section{ANÁliSE JURÍDICA DE AMBIENTE INSTITUCIONAL: IDENTIFICAÇÃO DE ATORES E GRUPOS DE INTERESSE}

Como primeiro passo para o exame proposto da política nacional de saneamento básico, é importante evidenciar algumas questões-chave de ordem macroinstitucional ${ }^{18}$ para o entendimento da forma como foram construídas as atuais instituições que conformam a política nacional de saneamento, bem como da forma com que as disputas redistributivas ${ }^{19}$ sobre os rumos da política ou sobre sua implementação se resolvem e influenciam o resultado concreto de efeitos políticosjurídicos. Em especial, o quadro constitucional de diretrizes normativas e de competências tem particular relevância para identificar os diversos atores e a forma como se posicionaram e se posicionam na dinâmica de construção da política. Tais normas jurídicas de ordem macro formam o que Douglass North e Lance Davis

\footnotetext{
${ }^{16}$ Immergut (1992, p. 83-85).

${ }^{17 /}$ Veto point analysis is a powerful tool and closely aligned with the type of strategic analysis that emerges from an understanding of games in extensive form. Veto points are essential variables in systems with checks and balances". (tradução livre: "A análise de oportunidades de veto é uma ferramenta poderosa e está alinhada com o tipo de análise estratégica que emerge da compreensão dos jogos de forma extensiva. Oportunidades de veto são variáveis essenciais em sistemas com freios e contrapesos"). Ostrom (1995, p. 175-176).

${ }^{18}$ Bucci (2013, p. 45-49). A autora faz a distinção de três planos diversos para as políticas públicas, o macroinstitucional, o mesoinstitucional e o microinstitucional.

${ }^{19}$ A política nacional de saneamento tem evidente caráter redistributivo, considerando a tipologia de Lowi (1966, p. 27-40) quanto às formas de distribuição de recursos apresentada.
} 
denominam ambiente institucional, definido como um conjunto regras políticas, sociais e jurídicas básicas que regem a atividade econômica e política. ${ }^{20} \mathrm{~A}$ Constituição Federal de 1988 trouxe de forma um tanto vaga a divisão de competências entre os entes federativos em matéria de saneamento. $\mathrm{O}$ inciso XX do artigo 21 dispôs ser de competência da União a definição de diretrizes gerais para o saneamento básico, assim como o artigo 23, parágrafo único, segundo o qual a competência para estabelecer normas de cooperação com os demais entes federativos em matérias de competência comum se dá por meio de lei complementar. Aos Municípios, a Constituição conferiu a titularidade dos serviços públicos de interesse local, conforme artigo 30, no qual estariam incluídos, por interpretação, os de saneamento básico. Já os Estados têm competência legislativa concorrente em conservação da natureza, recursos naturais e consumo, atividades relacionadas com saneamento básico e que, portanto, envolvem o ente federativo de alguma forma na regulação dos serviços, bem como a competência para, mediante lei complementar, instituir regiões metropolitanas para integrar a organização, o planejamento e a execução de funções públicas de interesse comum, de acordo com o artigo 25, $3^{\circ}$. Por fim, o artigo 23, inciso IX, traz como competência comum de União, Estados, Distrito federal e Municípios a promoção de melhoria das condições de saneamento básico. Desse quadro normativo macroinstitucional, que não traz definições bem delineadas acerca da competência de cada ente federativo e da forma de integração de suas ações, surge a primeira dicotomia de interesses, opondo, de um lado, os Municípios, e do outro, os Estados. Evidenciase, assim, a disputa, juridicamente qualificada, entre os que defendem que os serviços de saneamento devem ser prestados pelos Municípios e os que pugnam pela prestação a cargo dos Estados. Os argumentos de embasamento de cada uma das posições são muitos e transitam desde a seara puramente jurídico-dogmática, com o exercício exegético sobre o texto normativo constitucional, até razões de ordem técnica e econômica, como a integração e interdependência de redes e recursos hídricos. Pode-se dizer que a titularidade do serviço de saneamento foi, desde a vigência da Constituição de 1988 e mesmo antes dela, afirmada em regra e majoritariamente como sendo dos Municípios, em razão de atribuição de competência para assunção daquilo que for de interesse local. Os defensores da tese municipalista argumentam que a distribuição de água e a coleta de esgoto são atividades intrinsecamente locais, e o fato de haver etapas da cadeia que possam vir a transcender o território municipal, como a captação de água e o tratamento do esgoto, não são suficientes para descaracterizar o interesse local. ${ }^{21}$ Por outro lado, a visão estadualista, ou seja, a de que deveria caber aos Estados a titularidade do poder concedente, calcava-se no argumento de que isso seria necessário para manter a estrutura construída em torno do antigo plano, baseada na centralização

\footnotetext{
${ }^{20}$ Segundo Davis e North (1970, p. 133), “an Institutional Arrangement as an arrangement between economic units that govern the ways in which these units can cooperate or compete".

${ }^{21}$ Marques Neto (2005, p. 30).
} 
da prestação nas companhias estaduais de saneamento. ${ }^{22} \mathrm{O}$ segundo aspecto macroinstitucional importante para a conformação de expectativas sociais e o consequente delineamento de grupos de interesse é a disciplina, por parte da Constituição Federal, da forma de intervenção e atuação do Estado na economia e, consequentemente, a forma de prestação dos serviços públicos. Da leitura do artigo 173, pode-se inferir que a escolha político-jurídica da sociedade foi conferir ao Estado papel excepcional na exploração direta da atividade econômica, o que, contrario sensu, reconhece a necessidade, em regra, de atuação privada nas atividades econômicas em sentido estrito. $\mathrm{O}$ artigo 174 consagra o papel do Estado como agente regulador, fiscalizador, incentivador e planejador da atividade econômica. Já o artigo 175 atribui ao Estado a obrigação de prestação do serviço público. Porém, no mesmo dispositivo, evidencia-se que a prestação pode ser direta - por meio de órgãos, autarquias e assemelhados controlados pelo Poder Público ou sob o regime de concessão ou permissão. A Constituição, ao prever a possibilidade tanto de prestação direta quanto de delegação dos serviços públicos, faz surgir uma outra grande dicotomia de interesses. Trata-se da oposição entre os publicistas, quais sejam, os que defendem que a prestação de serviços de saneamento deve ser realizada diretamente pelo Estado, e os privatistas, que acreditam que os serviços de saneamento devem ficar a cargo da iniciativa privada, relegando ao Estado a função de fiscalizador e regulador.

A averiguação sobre esses elementos formadores do ambiente institucional delineia um quadro de interesses que é pressuposto para a compreensão da formação do arranjo, no plano mesoinstitucional e também do seu funcionamento da própria ação governamental por ele pautada, no plano microinstitucional, o que se tratará mais à frente.

\section{A trajetória CONDICIONANTE DE ASPECTOS JURÍDico- INSTITUCIONAIS DA POLÍTICA}

Como segunda etapa de análise, é importante descrever em linhas gerais como se deu a evolução de uma política ao longo da história, os momentos e formas de mudança estrutural ${ }^{23} \mathrm{e}$ o legado atual dessa estruturação, não de forma burocrática, mas naquilo que for necessário para apontar fatores relevantes à análise de aspectos concretos atualmente em curso e identificar a path dependency no caso concreto. Em um primeiro momento, a questão sanitária no Brasil foi, por força do federalismo da Constituição de 1891, relegada pela União aos Estados e, indiretamente, aos Municípios. O texto constitucional não mencionava explicitamente o saneamento, mas atribuía aos Estados a obrigação de prover, com recursos próprios, as necessidades da Administração, e garantia aos Municípios a autonomia em relação

${ }^{22}$ Ribeiro e Costa (2013, p. 477).

${ }^{23}$ Entendida aqui como a transformação significativa de seu arranjo jurídico-institucional e efeitos pretendidos. 
ao que fosse de "seu peculiar interesse" 24 . A preocupação com o tema ganhou relevância no início do século XX em razão de epidemias constantes que geraram preocupação nas elites politicas e as mobilizaram no sentido de exigir alguma atuação federal, já que Estados e Municípios não dispunham de meios adequados para tratar do problema. ${ }^{25}$. Com o advento da Constituição de 1934, afirmou-se a titularidade dos Municípios para o tratamento da questão do saneamento ${ }^{26}$, a despeito da falta de capacidades para lidarem de forma minimamente adequada à questão, e a descentralização caracterizava a prestação dos serviços, não havendo ações governamentais nacionalmente articuladas. O quadro institucional precário da época refletia nos baixos índices de fornecimento de água e esgoto ${ }^{27}$. A partir de meados da década de 1960, cresceu a preocupação do governo federal com a questão, o que se pôde verificar pelo Programa de Ação Econômica do Governo PAEG, no qual saúde e saneamento foram considerados conjuntamente no estabelecimento de diretrizes e metas, bem como em outros planos governamentais, como o Plano Nacional de Desenvolvimento Econômico e Social e o Plano Estratégico de Desenvolvimento. Foi criado o Fundo de Financiamento para o Saneamento, cuja gestão ficou a cargo do Banco Nacional de Habitação ${ }^{28}$, o qual, por sua vez, criou o Programa de Financiamento para Saneamento e estimulou a criação de diversos outros fundos regionais. Todas essas medidas, que já visavam à centralização e à busca da sustentabilidade financeira, viriam a culminar no Plano Nacional de Saneamento - PLANASA. Pode-se considerar, portanto, que o final da década de 60 e o início da década de 70 são marcos da intervenção do Estado brasileiro no setor de saneamento, sendo que, a partir de 1971, com o PLANASA vigente, tal padrão de intervenção assume o caráter de política nacional ${ }^{29}$ bastante robusta. Observa-se aqui uma mudança de cunho estrutural no papel do Estado relativamente ao saneamento, criando um arranjo institucional mais centralizado, em oposição à forma antes realizada por meio de autarquias e órgãos municipais, bem como com a criação de meios de financiamento, diretrizes e metas até então inexistentes. Houve grande foco na criação e desenvolvimento de companhias estaduais de saneamento básico, que viriam a assumir posição protagonista na gestão dos serviços públicos em detrimento dos Municípios. A expansão da infraestrutura demandada pelo

\footnotetext{
${ }^{24}$ Constituição de 1891: “Art 5ำ - Incumbe a cada Estado prover, a expensas próprias, as necessidades de seu Governo e administração; a União, porém, prestará socorros ao Estado que, em caso de calamidade pública, os solicitar (...) Art 68 - Os Estados organizar-se-ão de forma que fique assegurada a autonomia dos Municípios em tudo quanto respeite ao seu peculiar interesse".

${ }^{25}$ Costa e Sousa (2016, p. 621).

${ }^{26}$ Constituição de 1934: “Art 13 - Os Municípios serão organizados de forma que lhes fique assegurada a autonomia em tudo quanto respeite ao seu peculiar interesse (...)".

${ }^{27}$ Estudo do BNH referente ao ano de 1967, conforme Jacobi (1989, p. 24).

${ }^{28}$ Inicialmente, a gestão coube, por breve período, ao Departamento Nacional de Obras de Saneamento (DNOS).

${ }^{29}$ Saraiva (1987, p. 59-61).
} 
explosivo crescimento da população urbana, somada à necessidade estratégica de manutenção de tarifas sociais e congelamentos tarifários como forma de controle inflacionário, que ficavam a cargo das companhias estaduais, tornavam-nas insustentáveis do ponto de vista financeiro. Esse desequilíbrio era compensado por subsídios da União, por meio de empréstimos a fundo perdido e outros instrumentos, o que possibilitou a continuidade das atividades das companhias e, especialmente, uma evolução significativa no índice de cobertura, particularmente nas ligações à rede de água ${ }^{30}$. Ou seja, independentemente de falhas de concepção, houve, em razão do Plano, um avanço significativo nos indicadores de saneamento, ainda que concentrados no fornecimento de água. Esse modelo de expansão dos serviços, no entanto, perdurou somente até o fim da década de 80 . Os motivos pelos quais entrou em decadência se devem à crescente escassez de recursos federais necessários ao equilíbrio das finanças das companhias estaduais, em razão do agravamento da crise econômica brasileira, e, do ponto de vista político, à mudança do ambiente institucional a partir da Constituição de 1988. O modelo tornou-se juridicamente conflitante com o novo e papel que os Municípios passariam a desempenhar na federação e a repartição e competências no novo contexto do regime democrático. Nessa esteira, a década de 90 acabou se caracterizando por um vazio institucional normativo e pela falta de planejamento para o setor, agravado pela dificuldade de planejamento devido ao cenário de hiperinflação e instabilidade econômica.

Não obstante a decadência do modelo e até mesmo sua revogação jurídica formal, a falta de alternativas institucionais remeteu a uma permanência dos arranjos vigentes, muitas vezes até em situações essencialmente de fato, como, por exemplo, na cidade de São Paulo, em que, até meados da década de 2000, sequer existia contrato escrito entre o município e a Sabesp ${ }^{31}$. E mesmo depois da aprovação de um novo marco regulatório, essa influência ou inércia institucional, traço da path dependency, continuou a existir de forma condicionante da ação governamental, como será visto mais à frente.

\section{ARRANJO JURÍDICO-INSTITUCIONAL E ELEMENTOS DA POLÍTICA}

Arranjo jurídico-institucional pode ser definido, para os fins deste trabalho, como o "agregado de disposições, medidas e iniciativas em torno da ação governamental, em sua expressão exterior, com um sentido sistemático". ${ }^{32}$ É a estrutura ou conjunto normativo de uma política pública, ou seja, sua institucionalidade jurídica própria, que delimita competências, responsabilidades, atribui consequências, cria incentivos e sistematiza sua relação com outras políticas ${ }^{33}$. O arranjo institucional

\footnotetext{
${ }^{30}$ Costa e Sousa (2016, p. 624).

${ }^{31}$ Coutinho et al. (2006).

${ }^{32}$ Bucci (2013, p. 237).

${ }^{33}$ Bucci e Coutinho (2017, p. 324).
} 
de uma política deve conter um marco geral de ação (norma instituidora da política), com um quadro geral de organização do Poder Público, das autoridades competentes, decisões para a concretização e o embasamento geral das condutas dos agentes envolvidos ${ }^{34}$. Como ferramenta útil à melhor compreensão do arranjo, e terceira etapa da análise proposta, recorre-se ao uso do quadro de referência em políticas públicas ${ }^{35}$, o qual objetiva apontar os elementos de organização de uma política a partir da base jurídica, ressaltando sua ligação com aspectos políticos, econômicos e de gestão. Serão mencionados apenas alguns dos elementos formadores desse quadro ${ }^{36}$ como um primeiro contato com a forma de estruturação contemporânea da política de saneamento básico, que tem contornos demasiadamente complexos e que demandariam uma dedicação específica.

A base jurídica da atual política nacional é composta por textos normativos dos mais diversos níveis. O principal deles é a Lei 11.445/2007, marco regulatório do setor. Tem-se ainda seu decreto regulamentador, Decreto 7.217/2010, que detalhou as diretrizes da lei. Pode-se mencionar também a Resolução no. 33/2007 do Conselho das Cidades, que, entre outras medidas, estabeleceu prazos para os Municípios elaborarem os seus planos de saneamento básico, e a Resolução n⿳ํㅜ 75, que propôs conteúdos mínimos e orientações para elaboração dos planos municipais de saneamento. O Decreto 6.942/09 veio com o intuito de acelerar a elaboração do Plano Nacional de Saneamento, com a finalidade de internalizar as metas assumidas pelo Estado em razão dos Objetivos do Milênio ${ }^{37}$, diretrizes internacionais elaboradas no início dos anos 2000 no âmbito da Organização das Nações Unidas - ONU. Por fim, o decreto 8.141/13 e a portaria interministerial 571/13 instituíram o PLANSAB - Plano Nacional de Saneamento Básico ${ }^{38}$, documento bastante extenso de planejamento de 20 anos, já previsto na lei de 2007. Pode-se citar também a Medida Provisória 844/2018, que pretendeu alterar substancialmente o marco normativo, mas acabou perdendo a eficácia por não ter sido votada no prazo constitucional, e a Medida Provisória 868/2018, editada nos últimos dias do governo Michel Temer e de conteúdo similar, que também perdeu a eficácia em razão do esgotamento de prazo. Essas duas medidas provisórias propunham alterações significativas no arranjo, e serão objeto de comentários específicos mais à frente.

\footnotetext{
${ }^{34} \operatorname{Bucci}(2013$, p. 238).

${ }^{35}$ Bucci $(2015$, p. 07-11).

${ }^{36}$ São elementos do quadro de referência o nome oficial da política, as gestões governamentais nas quais foi implementada, sua base normativa, seu desenho jurídico-institucional, agentes governamentais e não governamentais, mecanismos jurídicos de articulação, escala e público-alvo, dimensão econômico-financeira, estratégia de implantação, funcionamento efetivo e aspectos críticos do desenho jurídico-institucional.

${ }^{37}$ Disponível em https://nacoesunidas.org/tema/odm/ Acesso em: 08 maio 2016.

${ }^{38}$ Referenciado no decreto também pela sigla PNSB. Porém, mais comumente referido como PLANSAB.
} 
Entre os atores governamentais relevantes na execução da política citam-se especialmente os Municípios, as companhias ou órgãos municipais de saneamento básico, os estados e as companhias estaduais de saneamento básico. Deve-se mencionar ainda os conselhos de participação, em especial o Conselho das Cidades, bem como antigo Ministério das Cidades, hoje ministério do Desenvolvimento Regional, o qual concentra funções de articulação federativa, especialmente de auxílio técnico aos Municípios. Já como atores não governamentais, devem ser mencionadas as empresas exploradoras de concessões de serviço de saneamento, que podem, mediante a participação em processos de licitação específicos para esse fim, exercer as atividades de fornecimento de água, coleta e tratamento de esgoto por concessão dos Municípios titulares. Por diversas razões, a participação dessas empresas no montante de usuários atendidos nacionalmente ainda é baixa. ${ }^{39}$ Também são atores não governamentais os usuários do serviço público e cidadão em geral que o controle social, um dos princípios da política positivado na Lei $11.445 / 07^{40} \mathrm{e}$ os agentes financiadores.

Contribuição importante da Lei 11.445/07 é a criação do SNIS - Sistema Nacional de Informações sobre Saneamento, que procura uniformizar a coleta e a disponibilização de dados sobre o setor. O sistema coleta e padroniza os dados sobre o setor, fornecendo informações essenciais para a correta identificação de problemas de planejamento e execução.

A alocação de recursos para custeio e financiamento das ações de saneamento é um dos pontos mais sensíveis da política, dado o alto custo da infraestrutura. Parte dessa conta é formada pelas tarifas pagas pelos próprios usuários e parte é proveniente de outros meios, como subsídios, diretos ou indiretos, tarifários e fiscais. Os subsídios, espécie de subvenção, são despesas públicas e sobre eles recaem as normas relativas ao direito financeiro da Lei 4.320/64 e os princípios jurídicos relacionados, como o da transparência ${ }^{41}$. O financiamento do saneamento básico no âmbito dos estados se apoia muito nos chamados subsídios cruzados, pelos quais localidades mais ricas e de maior viabilidade econômica subsidiavam, com tarifas maiores, localidades em que o serviço fosse menos viável ou que necessitassem de maiores investimentos ${ }^{42}$, mas nem sempre de forma transparente. Em termos de recursos públicos, a partir de 2007, houve um incremento dos investimentos em saneamento, especialmente em razão do PAC - Plano de Aceleração do Crescimento e do PAC2 ${ }^{43}$. O PLANSAB, de 2013, contém diagnóstico acerca dos investimentos realizados e aqueles previstos para a concretização das

\footnotetext{
${ }^{39}$ Associação Brasileira das Concessionárias Privadas dos Serviços Públicos. Dados disponíveis em

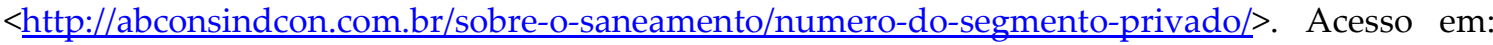
17 maio. 2017.

${ }^{40}$ Alochio (2010, p. 15).

${ }^{41}$ Câmara e França (2014, p. 37-63).

${ }^{42}$ Costa e Sousa (2016, p. 629).

${ }^{43}$ Albuquerque (2011).
} 
metas nele contidas para o período de 2014 a 2033. O documento, contudo, limitase a delinear três cenários diferentes para os investimentos federais, a depender de fatores conjunturais da economia, como o crescimento do PIB e relação dívida/PIB, os quais se mostraram desde o início absolutamente irreais. ${ }^{44}$

Tendo sido feito o delineamento geral do arranjo jurídico-institucional da política, com a visão do todo normativo organizado e principais elementos do quadro de referência, passa-se ao exame da dinâmica processual envolvendo o setor e seu desenvolvimento.

\section{O PROCESSO LEGISLATIVO E AS DISPUTAS SOBRE O NOVO MARCO NORMATIVO}

A ação governamental resulta de um conjunto de processos juridicamente regulados, expressão tomada em seu sentido amplo, não estritamente jurídico, como uma sequência de etapas institucionais de uma política pública, que vai desde a escolha de um problema para compor a agenda pública até sua efetiva implementação ${ }^{45}$. A análise de alguns desses processos como etapa final da visão jurídico-institucional aplicada pode trazer maior luz à compreensão sobre a política e seu funcionamento, o que se inicia pelo processo legislativo.

No início da década de 1990, em razão do conjunto de proposições e medidas econômicas liberalizantes, formulado por economistas e fomentado por instituições financeiras como o Fundo Monetário Internacional e o Banco Mundial como receituário para governos de países em desenvolvimento ${ }^{46}$, houve grande pressão para que o modelo antes eminentemente público passasse a integrar cada vez mais elementos que incluíssem a gestão privada num eventual novo arranjo institucional. Organismos internacionais frequentemente condicionavam o financiamento de projetos de desenvolvimento em áreas de infraestrutura à aceitação e implementação de postulados como a gestão privada de serviços, participação de investimento privado e a desestatização em geral ${ }^{47}$. Chegou a ser aprovado nas duas casas legislativas, inclusive, Projeto de Lei 199/93 (conforme nomenclatura assumida no Senado, ou PL 53/1991, nomenclatura da Câmara), de autoria da Deputada Irma Passoni, do Partido dos Trabalhadores, que instituía uma Política Nacional de Saneamento. O caráter geral do projeto era uma afirmação do

\footnotetext{
${ }^{44} \mathrm{O}$ Plansab estivou de fora excessivamente otimista o crescimento do PIB, antes mesmo da crise econômica de 2015, projetando para os anos futuros crescimento muito maior do que a média dos anos imediatamente anteriores.

${ }^{45}$ Bucci (2013, p. 109-110).

${ }^{46}$ Conhecidas também como Consenso de Washington, as dez medidas econômicas tomadas por essas instituições financeiras internacionais como receituário recomendado aos países em desenvolvimento estão descritas em artigo do economista John Williamson (1990, p. 05-20). Entre as recomendações, estão a adoção de política fiscal mais rígida, a desregulamentação, a abertura comercial e financeira e a privatização de estatais.

${ }^{47}$ Costa e Sousa (2016, p. 627).
} 
protagonismo do Estado na gestão e provimento dos serviços de saneamento, em detrimento da gestão e do investimento privado ${ }^{48}$. O projeto de lei, aprovado em etapa final no Senado em fins de dezembro de 1994, foi integralmente vetado pelo então Presidente Fernando Henrique Cardoso em 04 de janeiro de 1995, sob a justificativa de ser contrário ao interesse público. Pode-se afirmar que o arranjo proposto era incompatível com as diretrizes políticas do novo governo, que buscava, entre outras medidas, alterar o modelo de desenvolvimento econômico por meio de privatizações, o que não era encampado pelo novo marco aprovado no Congresso. Da análise da mensagem de veto nota-se o viés político liberal ao extremo ao taxar de excessiva burocratização instituições como plano quinquenal e um sistema nacional de coordenação do setor. Ou seja, pelas concepções do governo à época, o papel do Estado no setor não só não deveria ser o de prestador, como também as funções planejadora e coordenadora não seriam de sua alçada. Em oposição à visão do texto vetado, o Projeto de Lei do Senado 266/1996, de autoria do Senador José Serra, trazia as bases para uma nova política, alinhada com a ideia de privatização do setor, bem como com os defensores da titularidade estadual em regiões metropolitanas e conglomerados urbanos. Aprovado nas comissões permanentes, não chegou a ser votado, mas anexado a outras proposições ${ }^{49}$. Em oposição a essa iniciativa, estadualistas e municipalistas se reuniram constituindo um bloco organizado de defesa de interesses publicistas, chamado Frente Nacional pelo Saneamento Ambiental, em 1997, o qual foi decisivo para evitar a privatização em larga escala nos anos seguintes ${ }^{50}$. No início de 2001, o Executivo Federal apresentou novo projeto de lei, o PL 4.147/2001, congregando todas as diferenças de visão de Estado em relação ao anteriormente vetado. Porém, a união dos dois grandes grupos de interesse da época foi decisiva para que as iniciativas do governo federal no sentido de uma legislação liberalizante para o saneamento fossem frustradas, e o PL 4147/2001 acabou tendo sua tramitação interrompida. Observa-se que a manutenção do status quo se deveu tanto à oportunidade de veto (remetendo-se ao conceito criado por Immergut, anteriormente tratado) pela falta de sanção por parte do Executivo ao PL 53/1991 (PLC 199/93), quanto, em momento posterior, pelo exercício de oportunidades de veto por grupos de interesse quando da tramitação do PL 4147/2001.

Com a mudança de governo em 2003, deu-se a retomada das discussões acerca de um marco regulatório para o setor. Os dois grupos de interesse, que outrora estavam unidos em prol de um objetivo comum, agora novamente se separaram tornando a pressionar o Congresso pela aprovação de um marco que privilegiasse seus interesses próprios. O governo passou a ter de negociar distintamente tanto com os municipalistas quanto com os estadualistas. O governo apresentou, então,

${ }^{48}$ Conforme texto original publicado no Diário do Congresso Nacional, Seção I, página 1936 e seguintes, de 15 de março de 1991.

${ }^{49}$ Ribeiro e Costa (2013, p. 478).

${ }^{50}$ Sousa e Costa (2011, p. 3545). 
o PL 5.296/2005, na Câmara dos Deputados, formatado no âmbito do recém-criado Ministério das Cidades, a quem coube a função de formular a reestruturação por completo do setor. Previa novos instrumentos de gestão, subordinação a entidades de regulação, órgãos colegiados de controle social e fundos federativos de financiamento, além de afirmar a titularidade municipal do serviço. O projeto sofreu 862 emendas, a maioria delas contemplando os interesses dos estadualistas. Entre os pontos mais atacados estavam a instituição do SISNASA - Sistema Nacional de Saneamento (que previa a subordinação da ação e financiamento dos prestadores a normas instituídas pelo governo federal), a instituição de fundos federativos como meio de financiamento (em oposição aos subsídios cruzados), e a criação de conselhos deliberativos de políticas públicas para o setor. ${ }^{51}$ Cabe lembrar que, na prática, os subsídios cruzados, ao concentrarem nas companhias estaduais o excedente de arrecadação destinado a investimentos e expansão dos serviços, as deixavam totalmente no controle sobre a forma de distribuição e uso dos recursos, não permitindo a participação de outros atores interessados nesse processo. Os fundos federativos propostos, por sua vez, representariam um novo modelo de financiamento, mais acessível às reivindicações de outras partes interessadas, diminuindo assim o poder das companhias estaduais na gestão de recursos.

Paralelamente ao PL 5296/2005, o lobby dos estadualistas emplacou um outro projeto de lei no Senado (PLS 155/2005), que possuía caráter totalmente diverso daquele proposto pelo governo, alinhado aos estadualistas. ${ }^{52} \mathrm{~A}$ apresentação do projeto e o amplo apoio dos estados pressionou o governo federal para que negociasse com o lobby estadualista os pontos mais nevrálgicos da proposição. Por pressão desse grupo, a criação do SISNASA acabou ficando de fora do texto final, assim como a criação de fundos federativos e conselhos de participação social de caráter deliberativo. A questão da titularidade, inicialmente reafirmada no texto original como sendo dos Municípios, foi retirada do texto final aprovado, restando a lei omissa nesse ponto. A Lei 11.445/07, o marco do setor, foi sancionada com a aprovação do Projeto de Lei 7.361/06, resultado da negociação final com base no PL 5.296/05 e no PLS $155^{53}$.

O resultado final observado em termos de processo legislativo pode ser explicado, entre outros, por fatores atribuíveis à dependência de trajetória. Em meio ao vazio jurídico-institucional que caracterizou a década de 1990 até 2007, com a aprovação do novo marco normativo, o que se observou no setor de saneamento foram ações ditadas essencialmente pelos atores e grupos de interesse que já haviam se consagrado em meio ao arranjo institucional anterior. ${ }^{54}$ As companhias

\footnotetext{
51 Costa e Sousa (2016, p. 629).

52 Esse alinhamento fica claro, inclusive, no pronunciamento que fez o autor, ao Senador Gerson Camata, por ocasião da apresentação do projeto. Disponível em: <http://www25.senado.leg.br/web/atividade/pronunciamentos/-/p/texto/354185>. Acesso em: 04 jun. 2017.

${ }^{53}$ Demoliner (2008, p. 174).

${ }^{54}$ Costa e Sousa (2016, p. 632).
} 
estaduais, as quais eram responsáveis pelo serviço de água e esgoto na maioria dos Municípios durante a vigência de instrumentos contratuais singelos ou muitas vezes sem qualquer formalização escrita, decorrentes de imposições de "cima para baixo" durante o regime político autoritário no qual vigorou o PLANASA, continuaram como protagonistas no novo cenário, especialmente em razão das oportunidades de veto exercidas pelo lobby estadualista quando da tramitação do novo marco.

\section{O PROCESSO JUDICIAL COMO ROTA DE QUESTÕES NÃO RESOLVIDAS}

Aprovado o novo marco legal e depois de muito tempo e duas gestões governamentais ideologicamente contrapostas, foi superada a seara legislativa como o principal ambiente de performance e resolução de conflitos, mas as disputas não se encerraram. O processo judicial, como componente destinatário e canalizador de conflitos oriundos da efetivação de políticas, tem especial influxo, direto e indireto, sobre o desenvolvimento do setor de saneamento básico no Brasil, considerando especialmente a identificação de oportunidades de veto aplicada ao Poder Judiciário. A judicialização acerca da competência para a prestação do serviço de saneamento e, por consequência, a titularidade do poder concedente, se relaciona, desde o início, à disputa entre dois grandes grupos de interesse, os já mencionados estadualistas e municipalistas, e se deveu ao alto grau de dissenso entre os grupos de interesse no setor, que não teriam se mostrado minimamente capazes de, no advento do cenário de democracia, obter um consenso mínimo para a aprovação de um novo marco regulatório no âmbito legislativo. ${ }^{55} \operatorname{Logo}$, como decorrência dessa visão, a judicialização poderia ser tomada como uma consequência do fracasso da arena legislativa como meio para uma adequada (re)formulação da política pública. Em outras palavras, a inabilidade dos atores para produzir um consenso, por meio do processo legislativo, em torno de um tema que permitisse o desenrolar fluido da ação governamental, causou o deslocamento dessa disputa do Poder Legislativo para o Poder Judiciário.

A afirmação da relação de causa e consequência preconizada por esse tipo de análise tem a sua importância e não deve ser desprezada, especialmente se forem considerados todos os fatores de dependência de trajetória influenciadores das condutas dos diversos atores em um contexto novo de democracia ainda não devidamente aperfeiçoado para resolução de disputas no Legislativo. Porém, a visão jurídico-institucional de políticas públicas, e a utilização de caminhos advindos do neoinstitucionalismo histórico, permitem a exploração de uma hipótese distinta para explicar a judicialização do tema.

${ }^{55}$ Costa e Sousa (2016, p. 627). 
Para o cientista político Matthew Taylor, o protagonismo das cortes de justiça é mais presente no Estado brasileiro do que em outros. ${ }^{56}$. O autor analisou alguns casos concretos para apontar que o Judiciário, em especial o Supremo Tribunal Federal, acaba sendo uma importante - se não determinante - oportunidade de veto no processo de criação de uma política pública. Isso faz com que alguns grupos de interesse que não teriam, normalmente, poder de influir significativamente para formular ou barrar uma política no Legislativo, passem a ter excepcional poder de fazê-lo, como atores de veto no âmbito judicial de controle de constitucionalidade, quando o mérito jurídico de medidas aprovadas no Congresso é testado perante a corte máxima. Dessa maneira, considerando os mecanismos da Ação Direta de Inconstitucionalidade e seu regramento específico, o arranjo jurídico-institucional de controle de constitucionalidade, com seus procedimentos de controle concentrado e apontamento de determinadas partes legitimadas a contestar uma política diretamente no STF, cria-se um atalho para alguns atores políticos contestarem, de forma binária, a validade de uma determinada política consubstanciada em algum texto normativo cuja constitucionalidade seja posta em dúvida. Existiria, além disso, uma distribuição assimétrica de poder nessas situações, já que o acesso regular ao Judiciário por atores não contemplados como partes legitimadas para propositura de ADI confere uma forma diversa e menos favorecida de se contestar a validade de uma determinada política por meio das instâncias inferiores, enquanto alguns atores privilegiados teriam a via expedita da ADI para exercício dessa prerrogativa. Tal assimetria jurídica atribui a esses atores privilegiados uma oportunidade de veto que não acessível aos demais cidadãos, e não existente no processo legislativo e nas negociações políticas dele decorrentes. No caso do saneamento, com relação à definição da competência para prestar e conceder o serviço, o que se observou não foi o Judiciário invalidando uma política pública aprovada no Legislativo que afirmasse este ou aquele ente federativo como titular, como nos casos abordados por Taylor em seu artigo, mas sim uma situação de impasse jurídico, causado pelo mero exercício da prerrogativa de acesso privilegiado à oportunidade de veto judicial, sem uma resposta adequada por parte da corte. O caso paradigmático é o que envolve a edição da Lei Complementar $\mathrm{n}^{\mathrm{o}}$ 87/97 no Estado do Rio de Janeiro, que criou uma região metropolitana e invocou para o Estado a titularidade dos sistemas integrados de saneamento que compunham a Região Metropolitana do Rio de Janeiro, em razão da predominância de interesse comum. ${ }^{57}$ A ADI 1842, proposta pelo Partido Democrático Trabalhista em face da referida lei, só foi julgada pelo STF em 2013, nada menos que 15 anos após a edição das leis combatidas. Ou seja, a questão sobre a titularidade do serviço público de saneamento básico ficou pendente de decisão pelo Poder Judiciário quase 25 anos após a promulgação da Constituição Federal, marco da nova organização político-jurídica do Estado brasileiro em contexto democrático. É claro

\footnotetext{
${ }^{56}$ Taylor (2006).

${ }^{57}$ Conforto (2000, p. 173).
} 
que os desafios do setor transcendem o problema de titularidade. Porém, a questão tem até hoje influência indireta importante, ao não possibilitar que o planejamento da política se dê em bases jurídicas mais sólidas, com melhor atribuição e responsabilidades aos diferentes atores. Ilustrativo a esse respeito é o teor da Lei 11.445/07, aprovada em momento de indefinição sobre a questão, ou seja, anteriormente aos pronunciamentos judiciais mais relevantes. Percebe-se do texto normativo, por exemplo, que ele se esquiva de atribuir ou se referir à titularidade dos serviços de saneamento, seja para vinculá-la ao Município de forma inequívoca ou ao Estado nas regiões metropolitanas. Esse silêncio normativo contido na lei de diretrizes não é banal. $\mathrm{O}$ marco regulatório do setor pode também ter se omitido nesse sentido em razão da expectativa em torno do exercício da oportunidade de veto por qualquer dos atores - representada pela pendência de apreciação da ADI 1842 e outras relativas a regiões metropolitanas em diversas regiões do país. Ter como ponto de partida os corretos limites de responsabilidade jurídica e competência de cada ente federativo poderia ter feito substancial diferença no conteúdo final do texto normativo aprovado, com consequências práticas para a melhoria da eficiência na prestação do serviço. A discussão acerca do caráter da política e seu conteúdo poderia ter tido maior riqueza, precisão e criatividade se definidas previamente todas as competências e responsabilidades, com potencial ganho para uma melhor articulação e harmonização dos entes federativos, mas também de atores não governamentais, como concessionárias privadas de serviço público interessadas na exploração dos serviços de fornecimento de água, coleta e tratamento de esgoto, mas carentes de um grau razoável de segurança jurídica para planejamento econômico, quantificação e mitigação de riscos.

Outro aspecto da judicialização do tema do saneamento que torna clara a oposição de interesses entre estadualistas e municipalistas são as disputas, especialmente na década de 2000, sobre a retomada de serviços pelos Municípios, face ao término dos contratos de 30 anos firmados na época do PLANASA com as companhias estaduais. Além da polarização em torno dos entes federativos, podese dizer que essas disputas também opuseram, até certo ponto, os interesses das companhias estaduais, empresas estatais, e os interesses de investidores e operadores privados, novos atores entrantes que almejavam aumentar a participação na exploração direta da prestação de serviços de saneamento como concessionárias de serviço público, novamente a dicotomia publicistas $\mathrm{x}$ privatistas. O contexto de tais disputas era o de término iminente dos contratos ou atos de outorga em vigor, firmados na década de 70 , ou suas prorrogações sucessivas e precárias. Nesse cenário, uma série de Municípios intentou a retomada dos serviços para prestação direta por meio de autarquia municipal ou para eventual delegação, criando fortes resistências das companhias estaduais e, especialmente, dos governos estaduais, seus controladores. Tome-se como exemplo o caso do Município de Itajaí, em Santa Catarina. Em 1973, o município firmou contrato com a CASAN - Companhia Catarinense de Aguas e Saneamento. O 
contrato, de 30 anos, venceu em 2003 e o Município não somente não se manifestou pela renovação, como criou um órgão autônomo para assunção dos serviços, o SEMASA - Serviço Municipal de Água, Saneamento Básico e Infraestrutura de Itajaí. A CASAN, porém, recusou-se a entregar os serviços, exigindo, para tanto, o pagamento de prévia indenização pelos investimentos realizados. O Município, então, ingressou com ação cautelar inominada ${ }^{58}$ e obteve liminar determinando a reversão da concessão do serviço e a sua assunção pelo SEMASA. Note-se que, em que pese hoje a questão estar pacificada nas cortes superiores, na época havia, dentro do Tribunal de Justiça de Santa Catarina, duas posições antagônicas. De um lado, a jurisprudência da $2^{a}$ Câmara de Direito Público, para a qual seria indispensável o levantamento e avaliação de bens reversíveis, bem como a determinação e a quitação prévias do valor de indenização, sem o qual não seria possível a extinção da delegação pelo advento do termo contratual. De outro, a $1^{\text {a }}$ Câmara de Direito Público, para a qual, uma vez extinto o contrato de concessão por decurso do prazo de sua vigência, cabe ao titular a imediata retomada da prestação de serviços até a realização de nova licitação, sendo que eventual indenização deveria ser pleiteada pela companhia estadual pelas vias ordinárias. Observe-se que só a existência de entendimentos contrários, bem como uma expectativa de demora na pacificação jurídica sobre a questão, criou, para um determinado ator, uma oportunidade de veto juridicamente qualificada a impactar no resultado da ação governamental, representando uma vantagem desproporcional e um privilégio de influência decisória, a confirmar também a característica de dependência de trajetória tão inerente ao desenvolvimento atual do setor. Trata-se de um típico exemplo de como uma questão eminentemente jurídica, em razão de defeito de institucionalização das regras materiais concernentes ao assunto e também das regras processuais que adiam o desfecho jurídico-dogmático da controvérsia, cria indiretamente um privilégio a um ou mais grupos de interesse específicos, que podem, de modo não originalmente planejado ou desejado, influir nos rumos de uma política. Isso porque, independentemente do resultado dos processos judiciais em si, a mera possibilidade de reversão da decisão, ou de não confirmação do entendimento pelas cortes superiores, cria um ambiente de expectativas paralelo àquele intencionalmente planejado pelos arranjos institucionais, e acaba por conformar o comportamento dos mais diversos atores de forma diferente daquela estimada nas instâncias dotadas da legitimidade para tanto, em especial o Poder Legislativo.

\section{IMPACTOS NO PROCESSO GOVERNAMENTAL}

Os Estados e suas companhias de saneamento ainda são responsáveis pela maior parte dos serviços prestados, e têm uma influência muito grande nos rumos do serviço público de saneamento. A possibilidade de celebração de contratos com

${ }^{58}$ Autos n. 033.03.000923-8 da Vara da Fazenda Pública de Itajaí, SC. 
dispensa de licitação ${ }^{59}$ por serem entes da Administração Indireta, aliada à característica atual de governança das companhias, trouxe distorções para o curso natural do desenvolvimento das ações de saneamento. As companhias estaduais, com todo o peso político do Estado controlador, fizeram enorme pressão sobre os Municípios para que estes renovassem seus contratos de concessão firmados na década de 1970, não raro por até 30 anos. Alguns dos instrumentos de pressão consistem na cobrança de vultosas indenizações por conta da retomada dos serviços em razão do termo final do contrato ou a retenção de bens reversíveis, como no exemplo de Itajaí citado, além de outras formas que envolvam ações governamentais fora do âmbito das companhias estaduais. ${ }^{60}$ Por meio desses mecanismos, algumas companhias estaduais renovaram praticamente todos os seus contratos antigos com os Municípios, concorrendo com as concessionárias privadas interessadas de forma muito vantajosa, e tudo isso num contexto de ausência de uma nova política pública devidamente institucionalizada. Da mesma forma, se afigura bastante visível a forma desigual com que as instituições do período não democrático distribuíram desigualmente o poder no seio da ação governamental. $\mathrm{O}$ privilégio a determinados atores (no caso, as companhias estaduais de saneamento básico), lhes conferiu peso institucional tal que, mesmo diante de uma nova reconfiguração político-jurídica do Estado brasileiro e a despeito da reforma da legislação, foram decisivos para a manutenção de determinados quadros fáticos.

Mesmo antes de a questão chegar ao Judiciário, a existência em si de questões jurídicas mal resolvidas como essas representam oportunidades de veto no âmbito do próprio processo governamental, dado que fortalecem mais ou menos os grupos de interesse em eventuais negociações e formação de novos arranjos locais, como o modelo de exploração local e até mesmo de regulação. Todas essas incertezas se potencializam como obstáculos a qualquer mudança no status quo, na medida em que os Municípios são menores, menos providos de corpo técnico e jurídico especializados ou capacidade institucional, e, por outro lado, as companhias estaduais concentram know-how técnico e jurídico dedicado e interesses motivadores. São várias as oportunidades de veto juridicamente qualificadas, identificáveis no arranjo jurídico-institucional do setor, que se exprimem no âmbito do processo governamental e contribuem para que seja delineada uma assimetria

\footnotetext{
${ }^{59}$ Conforme artigo 24, inciso XXVI da Lei 8.666/93, com redação dada pela Lei 11.107/05: “Art. 24. É dispensável a licitação: [...] XXVI - na celebração de contrato de programa com ente da Federação ou com entidade de sua administração indireta, para a prestação de serviços públicos de forma associada nos termos do autorizado em contrato de consórcio público ou em convênio de cooperação."

${ }^{60} \mathrm{D}^{\prime}$ Amico e Valente (2009, p. 254). Cita-se como exemplo de caso concreto a assinatura do contrato de programa entre a Sabesp e o Município de Lorena em 2007, no curso do procedimento licitatório que objetivava a concessão do serviço à iniciativa privada, dias antes da data prevista para entrega das propostas.
} 
de poder que não se verifica de uma primeira leitura dos textos normativos, bem como não parece ter sido intencionalmente planejada na formulação. A disciplina de delegação dos serviços públicos de saneamento entre entes da Administração, que conta com um facilitador institucional - a possibilidade de dispensa de licitação para celebração de contratos de programa - é uma delas. Outra é a previsão de cláusulas, em antigos contratos de concessão com companhias estaduais de saneamento, que dispõem sobre pagamento de indenizações para retomada dos serviços sem que haja, ao mesmo tempo, critérios contratuais claros para a definição dessas indenizações. Esses dois elementos jurídicos dos arranjos, um deles um preceito positivo de tratamento desigual e outro uma lacuna aparente de norma a criar insegurança jurídica, podem ser utilizadas em conjunto ou separadamente por determinados atores (no caso, as companhias estaduais) para influenciar de modo privilegiado a forma como a operação dos serviços de saneamento de uma determinada localidade se dará, por até três décadas ou mais.

A despeito de o marco normativo da política nacional de saneamento permitir e prever de forma clara não somente a concessão dos serviços para empresas privadas, mas também a forma de relação entre público e privado, o acesso favorecido das companhias estaduais a decisões no âmbito do processo governamental dos titulares faz com que eventual disputa pela exploração dos serviços se dê em condições muito desiguais e incertas, desestimulando a participação das primeiras, que acabam buscando outras formas de atuação no setor que não sejam diretamente concorrentes com as empresas estatais, como subcontratações, sem que haja relação jurídica direta entre elas e os titulares ${ }^{61}$

Ademais, a questão em aberto a respeito das indenizações acaba sendo solucionada pelos Municípios, muitas vezes, da forma mais simples, isto é, pela renovação da concessão com as companhias estaduais mediante o atalho do contrato de programa sem licitação, com a disposição de forma mais clara sobre os bens reversíveis e suas amortizações no novo contrato. Ou seja, diante de um impasse criado pelo ambiente jurídico (o que não deixa de ser um problema de arranjo), o processo potencial de concessão de um serviço para um operador privado, que em tese poderia contribuir em capacidades gerenciais ou de financiamento, ou simplesmente pressionar o operador público a melhorar sua eficiência diante de alguma concorrência, acaba prejudicado. $\mathrm{O}$ veto pode ser exercido de forma privilegiada no processo governamental pelas companhias estaduais, para sustar algum processo de privatização em planejamento ou intenção, por meio de propostas agressivas de renovação ou mesmo de resistência jurídica fundamentada na possibilidade de cobrança de indenizações, criando consequências políticas desfavoráveis aos titulares e induzindo à composição. Pode ser exercido, também, por atores políticos distintos dos titulares, mas em posições

${ }^{61}$ Como, por exemplo, o Projeto de PPP da Sabesp em parceria com a Galvão Engenharia S.A. e Companhia Águas do Brasil (CAB Ambiental) para Sistema da Estação de Tratamento de Água de Taiaçupeba, amplamente noticiada à época de sua criação, em 2008. 
transitórias análogas (em especial os prefeitos eleitos), e também pelos Legislativos municipais. Considerando ainda a influência do processo eleitoral na dinâmica das políticas públicas e a variabilidade de posições políticas dos diversos candidatos, o maior ou menor alinhamento do chefe do Poder Executivo com determinadas linhas ideológicas ou mesmo com as gestões dos governos estaduais acaba por influenciar na opção ou não pela continuidade de uma disputa com o operador estadual, independentemente do interesse público efetivo.

Essa dinâmica, além de condicionar os comportamentos dos agentes para a manutenção de arranjos em que o operador é controlado pelo Estado, acaba também por moldar a própria forma como o investimento privado contribui para o setor, criando uma assimetria de poder entre o privado "sócio" do Estado e o privado "concorrente" do Estado, desfavorecendo este último. Isso porque, em alguns casos, as companhias estaduais possuem parte de suas ações nas mãos de acionistas privados, caso das sociedades de economia mista, o que traz questionamentos se essa é a melhor forma de incorporação da contribuição da iniciativa privada no setor e se esse modelo prestigia a isonomia e a livre iniciativa, para mencionar duas regras constitucionalmente postas. O prestigio desigual a soluções eminentemente baseadas na atuação direta do Estado, ou no capital privado "sócio" do Estado, observa-se da análise sistemática do arranjo e não parece se afigurar como escolha consciente, aberta e clara de uma agenda de política, mas sim expressa-se, de forma prática, nas entrelinhas e conjunções disfuncionais entre diversos subsistemas jurídicos que acabam por reforçar a dependência de trajetória e, consequentemente, o viés publicista estadualista.

Ainda com relação ao processo governamental, outro aspecto disfuncional do arranjo jurídico-institucional da política nacional de saneamento pode ser identificado ao se observar como a regulação foi tratada no marco normativo e como, na prática, ela se dá em diversas situações. Na Lei 11.445/2017, é concebido um modelo de regulação interessante, com definição bem clara do papel, obrigações e organização dos entes reguladores, e que parte do pressuposto, desenvolvido pela influência liberal da concepção dos serviços públicos, da figura do operador separada da figura do Estado. ${ }^{62}$ Justamente por essa razão, se afigura curiosa e um tanto incoerente uma forma de regulação atrelada ao modelo de operação majoritariamente estatal. Essa característica faz com que o papel de regulador, planejador e operador se concentrem, muitas vezes, no âmbito de um mesmo ente político, o que compromete potencialmente a independência e os resultados. É algo que ocorre, por exemplo, nos dois Estados mais populosos do país, São Paulo e Minas Gerais, nos quais, no âmbito da relação de negociação

${ }^{62}$ De acordo com Marques Neto e Garofano (2016, p. 75): “No cerne de tal redefinição da atuação estatal devem estar as entidades reguladoras independentes, cujo principal desafio consiste em disciplinar a atuação dos particulares a fim de emprestar maior efetividade e representatividade à pluralidade de interesses públicos legítimos coexistentes no corpo social, mantendo o controle da atividade por meio do exercício da função de regulação". 
política e jurídica entre Municípios e Estado sobre concessão ou renovação de concessão dos serviços de saneamento, é muitas vezes oferecido pelo Estado ao Município um "pacote" de soluções, consistente em auxílio com o plano de saneamento (suprindo a deficiência técnica de planejamento inerente aos Municípios), em delegação da regulação para ente estadual por meio de convênio (suprindo outra grande lacuna de capacidades institucionais) e, finalmente, em concessão do serviço a empresa pública ou sociedade de economia mista controlada pelo estado, por meio de assinatura de contrato de programa. Não raro, todas as minutas que consubstanciam juridicamente cada um dos atos do "pacote" são apresentados prontos para o Município, faltando praticamente apenas o cumprimento dos trâmites internos e autorizações legislativas necessárias. ${ }^{63}$ Essa situação fática evidencia uma distorção jurídica importante, ao concentrar, na prática, essas três funções - operação, regulação e planejamento - nas mãos de um mesmo ente, qual seja, o estado, e com o agravante de beneficiar também um interesse privado, qual seja, o dos acionistas privados da companhia estadual quando sociedade de economia mista. Essa sobreposição de interesses, competências e papéis poderia ter sido evitada com um texto mais claro da Lei 11.445/07, cujo silêncio sobre algumas matérias, como a possibilidade ou não de delegação do planejamento, pode ser por vezes interpretado como eloquente ${ }^{64}$, a estimular indevidamente esse tipo de prática. A assimetria de poder, do ponto de vista de capacidades técnicas, jurídicas e institucionais, entre os Municípios titulares do serviço público e os Estados (e seus braços operacionais, como as companhias estaduais de saneamento), causa efeitos práticos na definição dos modelos de operação e regulação muito mais intensos do que a assimetria de poder decorrente, pura e simplesmente, de uma aplicação em condições minimamente igualitárias dos dispositivos jurídicos do marco normativo. A ausência de elementos no arranjo jurídico-institucional que possam de alguma forma mitigar os efeitos dessa relação fática de poder extremamente desigual pode ser apontada como outra disfunção importante, evidenciada na prática por essa regulação público-público atípica, e representa, pela omissão, uma nova oportunidade de veto a conferir privilégios de influência não desejados no âmbito do processo governamental da política pública.

Por fim, deve-se pontuar que as tentativas recentes de tornar o arranjo jurídicoinstitucional do saneamento mais funcional e maximizar seus efeitos de concretização dos direitos sociais perseguidos pela política pública, em que pese pareçam se voltar justamente ao combate de alguns dos problemas jurídicoinstitucionais apontados, reforçam os sinais de desarticulação e de cooptação por

${ }^{63}$ Como exemplo, citam-se as tratativas entre a COPASA - Companhia de Saneamento de Minas Gerais e o Município de Lagoa Santa, documentadas nos autos de processo administrativo $\mathrm{n}$. $8579 / 2014$.

${ }^{64}$ SOUZA, Rodrigo Pagani de. Planejamento dos Serviços de Saneamento Básico na Lei Federal no 11.445 de 5 de janeiro de 2007. . In MOTA, Carolina (Coord.) Saneamento Básico no Brasil. Aspectos jurídicos da Lei Federal 11.445/07. São Paulo: Quartier Latin, 2010, p.38. 
interesses específicos sem prestígio à melhor dinâmica de atendimento ao interesse público. Nesse sentido, observa-se que o então Presidente da República Michel Temer editou, em 06 de julho de 2018, a Medida Provisória 844, cujo texto, em uma primeira leitura, parece endereçar as disfunções de arranjo acima apontadas, alterando a Lei 11.445/2007 em pontos sensíveis, dos quais destacam-se dois principais. Em primeiro lugar, aumentou a competência da Agência Nacional de Águas, atribuindo a ela uma função reguladora do saneamento de âmbito federal que antes não havia, concorrendo com a do Poder Concedente. Em segundo lugar, alterou substantivamente a prerrogativa de dispensa de licitação para celebração de contratos de programa com companhias estatuais de saneamento, tornando obrigatória a licitação quando houver outro interessado na exploração dos serviços, o que seria aferido por chamamento público ou Procedimento de Manifestação de Interesse. A exposição de motivos ressalta ser necessário aumentar a qualidade das normas de regulação, e atribui também à atual possibilidade de dispensa de licitação a redução da competição entre concorrentes que, em razão do monopólio natural, competem "pelo mercado e não no mercado". ${ }^{65}$ A Medida visava claramente atender aos interesses privatistas, os quais, na busca de aumentar sua participação nas concessões dos serviços, se beneficiariam da uniformização de regras de regulação no território nacional, bem como da obrigação de concorrência para a delegação, mesmo para empresa estatal. Mas tais diretrizes, desacompanhadas de outras medidas que mitigassem possíveis problemas decorrentes das alterações, como a deletéria inviabilização dos serviços em municípios menores e de operação dependente de subsídios cruzados, poderiam causar ainda mais distorções regulatórias. Umas dessas distorções é o chamado cream-skimming, em que os entrantes se interessam em prestar serviço apenas nos locais em que a atividade é superavitária, usufruindo de tarifas acima do custo marginal, mas abaixo das atualmente vigentes nesses locais considerando o subsidio cruzado que financia os locais deficitários ${ }^{66}$. Nessa hipótese, a despeito de uma provável diminuição da tarifa nessas localidades viáveis, a capacidade de investimento total do setor, especialmente nas áreas mais necessitadas, cairia, e se agravaria - ao invés de melhorar - a perspectiva de universalização dos serviços. A MP sofreu grande resistência pelos estadualistas e municipalistas, o que se observa da análise da tramitação da MP. Há numerosas manifestações críticas

\footnotetext{
${ }^{65}$ Conforme exposição de motivos, “[...] A MP proposta atribui a Agência Natural de Águas (ANA) a competência de elaborar normas nacionais de referência regulatória para o setor de saneamento básico, que servirão como balizadores das melhores práticas para os normativos dos diferentes reguladores de saneamento básico do País. [...]Destacadamente, a dispensa de licitação para a celebração de contratos de programa reduziu em demasiado a concorrência no setor de saneamento onde, por se tratar se um monopólio natural, os concorrentes competem pelo mercado e não no mercado."

${ }^{66}$ Cruz e Ramos (2016, p. 648).
} 
apensadas ${ }^{67}$, como moções de apelo e repúdio por parte de municípios, câmaras municipais e assembleias legislativas. $O$ texto foi ainda objeto de 525 emendas na Câmara dos Deputados e acabou perdendo a eficácia por decurso do prazo exigido para sua conversão em lei. Supreendentemente, no dia 27 de dezembro do mesmo ano, a quatro dias do término de seu mandato, o Presidente da República editou a MP 868/2018, reproduzindo praticamente na íntegra o texto da MP 844. É bastante emblemático da forma pouco cuidadosa com que o tema é tratado o fato de o governo federal submeter mudanças tão relevantes no marco regulatório ao alto risco de declaração de inconstitucionalidade, já que há vedação constitucional para reedição de MP na mesma sessão legislativa, o que já foi reconhecido pelo Supremo Tribunal Federal nas ADIs 5709, 5716 e 5717 em situações análogas. Ou seja, mesmo sob o prisma puramente do interesse privatista, a questão estaria mal encaminhada, já que redundaria em insegurança jurídica, postergação da definição sobre pontos estruturantes e, novamente, a devolução das decisões político-jurídicas do modelo para o Poder Judiciário. A MP 868 recebeu 501 emendas e, a exemplo da anterior, também perdeu eficácia por decurso de prazo. ${ }^{68}$

\section{CONCLUSÃo}

No presente artigo procurou-se discorrer sobre algumas das características e disfunções no arranjo jurídico-institucional da política nacional de saneamento básico, na linha da abordagem de Direito e Políticas Públicas, tomando como ponto de partida premissas de método do neoinstitucionalismo histórico, trazidas da ciência política, somando-as com a utilização do ferramental proporcionado pela dogmática jurídica para ampliação das possibilidades de análise. Pôde-se identificar como as diversas visões e interesses influíram sobre a construção do marco normativo do setor de saneamento até que se chegasse a um termo final com a Lei 11.445/07, e de que maneira esses embates refletem no funcionamento prático da política e seu arranjo jurídico-institucional. Procurou-se demonstrar como a omissão legislativa contribuiu para um cenário de embate judicial de interesses que criou insegurança jurídica, além de propiciar oportunidades de veto a determinados atores, com destaque às companhias estaduais, favorecendo as situações fáticas já consolidadas e distorcendo a aplicação jurídica do marco normativo tal qual foi aprovado pelo Legislativo. Evidenciou-se o impacto que a indefinição sobre indenizações de bens reversíveis trouxe à ação governamental, discussão cuja existência, por si só, já surtiu distorções e privilégios a determinados atores no processo governamental. A conclusão geral é de que elementos de caráter político e jurídico se combinaram para criar disfunções no arranjo jurídico-

67 Disponível em https://www.congressonacional.leg.br/materias/medidas-provisorias/Lmpv/133867. Acesso em 12 jun. 2019.

${ }^{68}$ Até a conclusão deste artigo, tramitavam no Congresso Nacional diversas outras proposições legislativas recentes visando alterar de forma relevante o marco regulatório, como o PL 3.261/2019, PL 3.189/2019, PL 3.235/2019, PL 10.996/2018, PL 3620/2019 e PL 3.770/2019. 
institucional da política de saneamento básico, alterando de forma prejudicial o seu funcionamento.

\section{REFERÊNCIAS}

ALBUQUERQUE, Guilherme da Rocha. Estruturas de financiamento aplicáveis ao setor de saneamento básico. BNDES Setorial, n. 34, p. 45-94, 2011. Disponível em: <http://www.bndes.gov.br/SiteBNDES/export/sites/default/bndes pt/Galerias/Arq uivos/conhecimento/bnset/set3402.pdf>. Acesso em: 12 maio 2016.

ALOCHIO, Luiz Henrique Antunes. Direito ao saneamento: introdução à lei de diretrizes nacionais de saneamento básico. Campinas: Millenium, 2010.

BUCCI, Maria Paula Dallari. Fundamentos para uma Teoria Jurídica das Políticas Públicas. São Paulo: Saraiva, 2013.

BUCCI, Maria Paula Dallari. Notas para uma metodologia jurídica de análise de políticas públicas. Fórum Administrativo: Direito Público, v. 9, n. 104, p. 20-34, 2009. Disponível em: $<$ http://dspace/xmlui/bitstream/item/5816/PDIexibepdf.pdf?sequence=1 $>$. Acesso em: 09 set. 2016.

BUCCI, Maria Paula Dallari. Quadro de referência de uma política pública. Primeiras linhas de uma visão jurídico-institucional. In: SMANIO, Gianpaolo Poggio; BERTOLIN, Patrícia Tuma; BRASIL, Patrícia Cristina (Orgs.). O Direito na Fronteira das Políticas Públicas. São Paulo: Páginas e Letras Editora e Gráfica, 2015. p. 7-11.

BUCCI, Maria Paula Dallari; COUTINHO, Diogo R.; Arranjos jurídicoinstitucionais da política de inovação tecnológica: uma análise baseada na abordagem de direito e políticas públicas. In: COUTINHO, Diogo R.; FOSS, Maria Carolina; MOUALLEN, Pedro Salomon B.(Orgs.). Inovação no Brasil: avanços e desafios jurídicos e institucionais. São Paulo: Blucher, 2017.

CÂMARA, Camila G; FRANÇA, Vladimir da Rocha. O subsídio cruzado na política nacional de saneamento básico como mecanismo de garantia ao desenvolvimento sustentável e aos direitos fundamentais. In: CUNHA, Belinda Pereira da; SILVA, Maria dos Remédios Fontes; DOMINGOS, Terezinha de Oliveira (Orgs.). Direito e Sustentabilidade. João Pessoa: CONPEDI, 2014. 
CONFORTO, Glória. A regulação e a titularidade dos serviços de abastecimento de água e esgotamento sanitário no Brasil. Revista de Administração Pública, v. 34, n. 5, p.165-80, 2000.

COSTA, Nilson do Rosário; SOUSA, Ana Cristina A. de. Política de saneamento básico no Brasil. História, Ciências, Saúde, v. 23, n. 3, p. 615-634, 2016.

COUTINHO, Diogo Rosenthal et al. Poder Concedente e Marco Regulatório no Saneamento Básico. Cadernos Direito GV, v. 2, n. 2, Relatório de Pesquisa n. 10, 2006.

CRUZ, Karlos Arcanjo da; RAMOS, Francisco de Sousa. Evidências de subsídio cruzado no setor de saneamento básico nacional e suas consequências. Nova Economia, v. 26, n. 2, p. 623-651, 2016.

D'AMICO, Rafael Gandara; VALENTE, Sergio R. D. P. Contrato de Programa, regulação estadual e o setor de saneamento básico: comentários à luz de alguns dos recentes acontecimentos no Estado de São Paulo. In: PICININ, Juliana et al. (Org.). Saneamento Básico - Estudos e pareceres à luz da Lei 11.445/2007. Belo Horizonte: Editora Fórum, 2009.

DAVIS, Lance; NORTH, Douglass. Institutional Change and American Economic Growth: A First Step Towards a Theory of Institutional Innovation. The Journal of Economic History, v. 30, n. 1, p. 131-149, 1970.

DEMOLINER, Karine Silva. Água e saneamento básico: regimes jurídicos e arcos regulatórios no ordenamento brasileiro. Porto Alegre: Livraria do Advogado, 2008.

FREITAS, José Carlos de. Água, Saneamento e Saúde. In: BENJAMIN, Antonio Herman (Org.). Direito, água e vida, v. 2. São Paulo: Imprensa Oficial, 2003.

HALL, Peter A.; TAYLOR, Rosemary, C. R. Political Science and the Three New Institutionalisms. Political Studies, n. 44, p. 936-957, 1996.

IMMERGUT, Ellen. The rules of the game: The logic of health policy-making in France, Switzerland and Sweden. In: STEINMO, Sven; THELEN, Kathleen; LONGSTRETH, Frank. Structuring Politics. Historical Institutionalism in Comparative Analysis. Cambridge: Cambridge University Press, 1992. 
INSTITUTO TRATA BRASIL. Benefícios econômicos da expansão do saneamento brasileiro. São Paulo: FGV/IBRE, 2010. Disponível em:

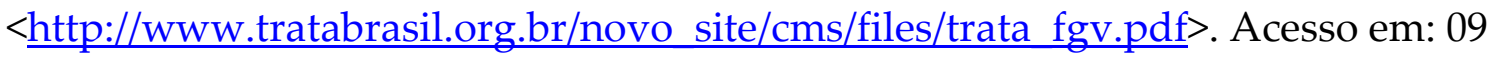
maio 2016.

JACOBI, Pedro. Movimentos sociais e políticas públicas: demandas por saneamento básico e saúde. São Paulo: Cortez, 1989.

LOWI, Theodore J. Distribution, regulation, redistribution : the functions of government. In: RIPLEY, Randall Butler. Public policies and their politics: an introduction to the techniques of government control. New York: Norton, 1966.

MARQUES NETO, Floriano de Azevedo. As parcerias público-privadas no saneamento ambiental. Revista eletrônica de Direito Administrativo Econômico, Salvador, n. 2, 2005. Disponível em:

<http://www.direitodoestado.com.br/redae/edicao/02>. Acesso em: 02 out. 2017.

MARQUES NETO, Floriano de Azevedo; GAROFANO, Rafael Roque. Notas sobre o Conceito de Serviço Público e suas Configurações na Atualidade. Revista de Direito Público da Economia, v. 46, p. 63-77, 2014.

OSTROM, Elinor. New horizons in institutional analysis. American Political Science Review, v. 89, n. 1, p. 174-178, 1995.

PIERSON, Paul. Increasing Returns, Path Dependence, and the Study of Politics. The American Political Science Review, v. 94, n. 2, 2000, p. 251-267.

RIPLEY, Randall B. Stages of the policy process. In: MC COOL, Daniel (Org.). Public Policy. Theories, Models and Concepts. An Anthology. New Jersey: Prentice Hall, 1995.

RIBEIRO, Wladimir Antonio; COSTA, Silvano Silvério da. Dos porões à luz do dia. Um itinerário dos aspectos jurídico-institucionais do saneamento básico no Brasil. In: CASTRO, Esteben José; HELLER, Leo (Orgs.). Política Pública e gestão de serviços de saneamento. Belo horizonte: Fiocruz, 2013.

SARAIVA, Flávio Mesquita. A política de Saneamento básico Pós-64, um novo modelo de Intervenção do Estado Brasileiro. Pesquisa e debate: Revista do 
Programa de Estudos Pós-graduados em Economia da PUC-SP, n.3, p.59-72, 1987.

SECRETARIA NACIONAL DE SANEAMENTO AMBIENTAL. Plano Nacional de Saneamento - PLANSAB. Brasília: Ministério das Cidades, 2013. Disponível em: $<$ http://www.cidades.gov.br/images/stories/ArquivosSNSA/Arquivos PDF/plans ab 06-12-2013.pdf>. Acesso em: 06 nov. 2016.

SOUSA, Ana Cristina Augusto de; COSTA, Nilson do Rosário. Ação coletiva e veto em política pública: o caso do saneamento no Brasil (1998-2002). Ciênc. saúde coletiva, v. 16, n. 8, p. 3541-3552, 2011.

SOUZA, Celina. Estado da Arte da Pesquisa em Políticas Públicas. In: HOCHMAN, Gilberto; ARRETCHE, Marta; MARQUES, Eduardo. Políticas Públicas no Brasil. Rio de Janeiro: Fiocruz, 2007.

SOUZA, Rodrigo Pagani de. Planejamento dos Serviços de Saneamento Básico na Lei Federal no 11.445 de 5 de janeiro de 2007. In: MOTA, Carolina (Coord.).

Saneamento Básico no Brasil: Aspectos jurídicos da Lei Federal 11.445/07. São Paulo: Quartier Latin, 2010.

TAYLOR, Matthew M. Veto and Voice in the Courts: Policy Implications of Institutional Design in the Brazilian Judiciary. Comparative Politics, v. 38, n. 3, p. 337-355, 2006.

TORRES, Ricardo Lobo. Curso de Direito Financeiro e Tributário. 18. ed. Rio de Janeiro: Renovar, 2011.

WILLIAMSON, John. What Washington Means by Policy Reform. In: MARQUES NETO, Floriano de Azevedo (Ed.). Latin American Readjustment: How Much has Happened. Washington: Institute for International Economics, 1990.

ZEHAVI, Amos J. Veto Players, Path Dependency, and Reform of Public Aid Policy toward Private Schools: Australia, New Zealand, and the United States. Comparative Politics, v. 44, n. 3, p. 311-330, 2012. 